\title{
Proniosome: A Novel Non-ionic Provesicules as Potential Drug Carrier
}

\author{
Khanderao R. Jadhav ${ }^{1}$, Ashish Y. Pawar ${ }^{1}$, Ashwini A. Bachhav', \\ Satish A. Ahire ${ }^{2}$ \\ ${ }^{1}$ Department of Pharmaceutics, MGV'S Pharmacy College, Nashik, Maharashtra, India, \\ ${ }^{2}$ Department of Chemistry, MGV'S A.S.C. College, Nashik, Maharashtra, India
}

\begin{abstract}
Vesicular systems are a novel means of drug delivery that can enhance the bioavailability of encapsulated drug and provide therapeutic activity in a controlled manner for a prolonged period of time. Liposomes were the first such system, but they suffer from a number of drawbacks including high cost and lack of stability at various pHs. To avoid the drawback of liposomes, niosomes were invented, which can be easily and reliably made in the laboratory. Niosomes are the ideal means of drug delivery that can enhance the bioavailability of encapsulated drug by various mechanisms and provide a therapeutic activity for a prolonged period of time. However, they suffer from aggregation, fusion, leaking, sedimentation of vesicles, and difficulty in sterilization; so to overcome these problems, a newer approach was employed which is known as pro-vesicular carriers. Here, in this review, we elaborate one of the pro-vesicular carriers, widely known as proniosome. This review covers all the aspects of proniosomes including mechanism, formulation variables and their effects, methods of preparation, parameters for characterizations, and application.
\end{abstract}

Key words: Niosomes, non-ionic, proniosomes, provesicles

\section{INTRODUCTION}

A $\mathrm{n}$ ideal controlled drug delivery system should possess two characteristics: The ability to release active pharmaceutical ingredients in a controlled manner and the ability to reach it's therapeutic targets. One of the ways to modify the original biodistribution of drug is to entrap them in submicroscopic drug carriers such as particulate, polymeric, macromolecular and cellular. Particulate type carrier, also known as a colloidal carrier system, includes lipid particles, microspheres, polymeric micelle, nano particles, and vesicles. The vesicular systems are highly ordered assemblies of one or several concentric lipids by layers, when certain amphiphilic building blocks are confronted with water. ${ }^{[1]}$

In short, vesicular drug delivery is one of the approaches which encapsulate the drug. The advantage of this system over other conventional dosage forms is their particulate nature, which acts as drug reservoir. It was found that modified vesicles had properties that successfully delivered drugs by doing few modifications in pattern and drug release. ${ }^{[2]}$
The types of vesicular drug delivery system are as follows:

1. Liposomes $^{[3]}$

2. Virosomes ${ }^{[4]}$

3. Niosomes ${ }^{[5]}$

4. Enzymosomes ${ }^{[6,7]}$

5. Transferosomes ${ }^{[8,9]}$

6. Protaosomes ${ }^{[10]}$

7. Sphingosomes ${ }^{[11]}$

8. Archaesomes ${ }^{[12,13]}$

9. Ethosomes ${ }^{[14,15]}$

10. Pharmacosomes. ${ }^{[16]}$

Drug delivery systems using colloidal particulate carriers (such as liposomes or niosomes) have proved to possess distinct advantages over the conventional dosage forms because the particles can acts as drug reservoirs, can carry both hydrophilic and hydrophobic drugs, and modification

\section{Address for correspondence: \\ Ashwini A. Bachhav, Department of Pharmaceutics, MGV'S Pharmacy College, Panchavati, \\ Nashik - 422 003, India. Phone: +91-9503238305. \\ E-mail: ashwini27212@gmail.com}

Received: 26-06-2016

Revised: 21-07-2016

Accepted: 30-07-2016 
of the particle composition or surface can adjust the drug release rate and/or affinity for the target site. All the vesicles in a dispersed aqueous system may suffer from some chemical problems associated with the degradation by hydrolysis or oxidation as well as physical problems such as sedimentation, aggregation, or fusion during storage. ${ }^{[17]}$

The provesicular concept has evolved to resolve the stability issues pertaining to the conventional vesicular systems, i.e., liposome and niosome. Pro-vesicular systems are composed of water-soluble porous powder as a carrier, upon which one may load phospholipids/non-ionic surfactants (liposome or niosomes, respectively) and drugs dissolved in organic solvents. The resultant dry-free flowing granular product which is formed could be hydrated immediately before use, and because of this reason, it can avoid various problems associated with aqueous vesicular dispersions. It is the newly emerging concept that demonstrates the potential of pro-liposomes/pro-niosomes in improving the oral bioavailability and permeation of drugs across the stratum corneum. Based on the investigation, it is clear that provesicular systems appear to be an alternate drug carrier for various route of drug administration. It can avoid many problems associated with aqueous vesicular dispersions. ${ }^{[18]} \mathrm{To}$ overcome the limitations (especially chemical and physical stability) of vesicular drug delivery systems like such as liposomes, niosomes, and transferosomes, the provesicular approach was introduced. ${ }^{[19]}$

This includes:
a. Pro-liposomes
b. Pro-niosomes
c. Dry granular liposomes
d. Mixed miceller liposomes
e. Pro-transfersomes.

\section{PRO-NIOSOME}

Pro-niosomes are liquid crystalline compact niosomal hybrid which could be converted into niosomes upon hydration with water. ${ }^{[20]}$ From the early 1980, proniosomes have gained a wide attention by researchers for their use as drug-targeting agents and drug carriers to have various advantages while avoiding disadvantage with the conventional dosage form. Niosomes are water-soluble carrier particles, and these are dried to form niosomal dispersion on brief agitation in hot aqueous media. This dehydrated product is pro-niosome. The niosomes which are obtained are more correlative to conventional niosomes and of higher size uniformity. The additional merits with pro-niosomes are low toxicity owing to non-ionic nature, no requirements of special precautions, and conditions for formulation and preparations. ${ }^{[21]}$ In addition, it is a simple method for the routine and large-scale production of pro-niosomes without the use of undesirable solvents. ${ }^{[22,23]}$

\section{ADVANTAGES OF PRO-NIOSOMES}

The advantages of pro-niosomes are as follows:

1. Avoiding the problems of physical stability such as fusion, aggregation, sedimentation, and leakage on storage $^{[24]}$

2. Avoiding the problem of chemical stability like hydrolysis of encapsulated drugs which limits the shelf life of the dispersion ${ }^{[24]}$

3. Ease of storage and handling ${ }^{[25]}$

4. No difficulty in sterilization, transportation, distribution, storage uniformity of dose, and scale-up ${ }^{[26]}$

5. Drug delivery improves bioavailability and minimum side effects ${ }^{[27]}$

6. It shows controlled targeted and sustained release of drugs due to depot formation ${ }^{[27]}$

7. It can entrap both hydrophilic and hydrophobic drugs $\mathrm{s}^{[27]}$

8. It is biodegradable, biocompatible, and non-immunogenic to the body ${ }^{[27]}$

9. The shape, size, composition, and fluidity of niosomes drug can be controlled when required. ${ }^{[27]}$

\section{ACTION OF PRONIOSOME}

Proniosome is a middle state of niosome formation as shown in Figure 1. The conversion of proniosome formulation into niosomes can be achieved by two-ways. ${ }^{[28,29]}$

1. Hydration by skin: The hydration is achieved by skin itself, i.e., the water in the skin is used to hydrate the proniosome formulation and conversion to niosomes.

2. Hydration by solvents: Aqueous systems, i.e., purified water, saline solution, and buffers are used to convert proniosomes into niosomes with or without agitation and sonication. ${ }^{[30,31]}$

\section{FORMATION OF NIOSOMES FROM PRONIOSOMES}

The niosomes can be prepared from the pro-niosomes by adding different types of aqueous phase with the drug to the proniosomes with brief agitation. and formation of noisome from proniosome shown in Figure 2.

$\mathrm{T}>\mathrm{Tm}$

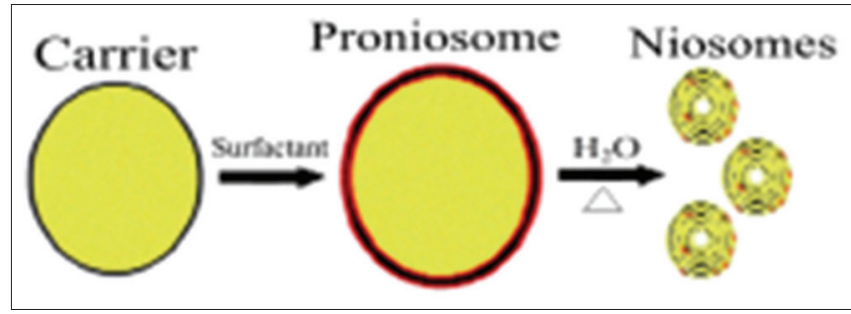

Figure 1: Action of niosome from proniosome ${ }^{[21]}$ 
Where, $\mathrm{T}=$ Temperature,

$\mathrm{Tm}=$ Mean phase transition temperature.

Blazek-Walsh et al. have reported the formulation of niosomes from maltodextrin based proniosomes. This provides a rapid reconstitution of niosomes with minimal residual carrier. In that slurry of maltodextrin, surfactant was dried to form freeflowing powder, which could be rehydrated by adding warm water. ${ }^{[33-36]}$

\section{STRUCTURE OF PRONIOSOMES ${ }^{[37,38]}$}

Proniosomes are microscopic lamellar structures. They combine a non-ionic surfactant and cholesterol followed by hydration in aqueous media. The surfactant molecule direct themselves such that the hydrophilic ends of the nonionic surfactant orient outward, while the hydrophobic ends are in the opposite direction to form the bilayer. Both the liposomes and proniosomes are made from bilayer, but the liposome's bilayer is made up from phospholipid whereas proniosomes bilayer is made up from non-ionic surface active agents. Formation of unilamellar or multilamellar proniosome also depend on the method of preparation.

The niosome is made of a surfactant bilayer with its hydrophilic ends exposed on the outside and inside of the vesicles while the hydrophobic chains (both) face each other within the bilayer. Because of this reason, the proniosomes hold both hydrophilic as well as hydrophobic drugs. Hydrophilic drugs hold within the space enclosed in the vesicle and the hydrophobic drugs are embedded within the bilayer.

Proniosomal gel is present in transparent, translucent or a semisolid gel structure. Because of limited solvent presence, the formed proniosomes are a mixture of phases of liquid crystal such as lamellar, hexagonal, and cubic. Here, the lamellar phase showed sheets of surfactant arranged in bilayer, hexagonal phase which showed the cylindrical compact structure arranged in a hexagonal fashion whereas cubic phase consists of curved continuous lipid bilayer extending to three dimensions. ${ }^{[39]}$

\section{TYPES OF PRONIOSOMES}

Depending upon the method of preparation, proniosomes exist in two forms.

\section{Dry granular proniosome}

According to the type of carrier and method of preparation of dry granular proniosomes are again divided into:

1. Sorbitol-based proniosomes

2. Maltodextrin-based proniosomes.
Sorbitol-based proniosomes are a dry formulation that involves sorbitol as a carrier, which is further coated with non-ionic surfactant and by the addition of hot water followed by agitation, it is used as a niosome within minutes and these are prepared in organic solvents on to the sorbitol powder and then evaporating the solvents. Because of this reason, sorbital carrier is soluble in organic solvent, the process is required to be repeated till the desired surfactant coating has been achieved. The advantage of Sorbitol based proniosomes is size distribution uniformity. It is useful in case where the active ingredient is susceptible to hydrolysis. The disadvantage of this proniosome is that the residual sorbitol decreases the entrapment efficiency to less than one-half of that observed without sorbitol. These necessitate reduction in the proportion of carrier in final niosomal suspension. The difficulty lies in the testing of sorbitol particles because sorbitol is soluble in chloroform and organic solvents. It is prepared by slow spraying method.

Maltodextrin-based proniosomes are prepared by fast slurry method. Time required to produce proniosomes by slurry method is independent of the ratio of surfactant solution. Proniosomes of high surface-to-carrier's ratio can be prepared. The method of obtaining niosomes from such a proniosomes for the drug deliver is very simple. Maltodextrin is a polysachharide that is easily soluble in water and it is used as carrier material in formulation. Maltodextrin morphology is preserved, and hollow-blown maltodextrin particles can be used for a significant gain in the surface area. The higher surface area results in thinner surfactant coating, which makes the rehydration process efficient. This preparation has the potential of application in delivering of hydrophobic and amphiphilic drugs. ${ }^{[34,40]}$

\section{Liquid crystalline proniosomes}

When the surfactant molecules are kept in contact with water, there are three ways through which lipophilic chains of surfactants can be transformed into a disordered, liquid state called lyotropic liquid crystalline state (neat phase). ${ }^{[38]}$ These three ways are increasing temperature at Kraft point (Tc), addition of solvent which dissolve lipids, and use of both temperature and solvent. Neat phase or lamellar phase contains bilayers arranged in a sheet over one another within intervening aqueous layer. This type of structure gives typical X-ray diffraction and thread like birefringent structure under polarized microscope. In short, the basic mechanism in liquid crystalline proniosomes is ternary lecithin, non-ionic surfactants as monoglyceride and alcohol system, lamellar liquid crystals are formed at Kraft temperature in the presence of alcohol. The lamellar crystalline phase is converted into dispersion of niosomes at higher water concentration. This type of organization of lipid/ethanol/water mixture into lamellar structure can be conveniently utilized for transdermal of drugs. The liquid crystalline proniosomes and proniosomal gel act as a reservoir for the transdermal delivery of active 
pharmaceutical ingredients. The transdermal patch involves an aluminum foil as a baking material along with the plastic sheet of suitable thickness stuck to foil by means of adhesive. Proniosomal gel is spread evenly on the circular plastic sheet followed by the covering of nylon mesh. ${ }^{[41]}$

This method avoids the use of pharmaceutically unacceptable solvents and it is easy to scale-up. As the formulation is in direct contact with the skin, it acts as a penetration enhancer in proniosomes which significantly enhanced the transdermal flux of drug (e.g., nisoldipine), compared with a saturated aqueous drug solution and proniosome without penetration enhancer. ${ }^{[42]}$

\section{MECHANISM OF VESICLE FORMATION IN PRONIOSOMES}

Vesicle formation in proniosomes depends on the ability of nonionic surfactant to form bilayer vesicles instead of micelles which depends on the following three parameters:

1. Hydrophilic-lipophilic balance (HLB) values of the surfactant

2. Chemical structure of the components

3. Critical packing parameter (CPP).

Proniosomes have a tendency to vesicle forming which is similar to niosomes. CPP can be defined as the relationship between the structure of surfactant including the size of hydrophilic head group and length of hydrophobic alkyl chain in the ability to form vesicles.

It is described as,

$$
\mathrm{CPP}=\frac{\mathrm{V}}{\mathrm{lc} \times \mathrm{a}}
$$

Where, $\mathrm{v}=$ The hydrophilic group volume, $\mathrm{lc}=$ Critical hydrophobic group length and $\mathrm{a}=$ Area of the hydrophilic head group.

After calculating CPP, when the value of CPP is between 0.5 and 1 , it indicates that the surfactant is likely to form vesicles. A CPP of below 0.5 (indicating a large contribution from the hydrophilic head group area) is said to give spherical micelles and a CPP of above 1 (indicating a large contribution from the hydrophobic group volume) should produce inverted micelles which on later stages give precipitation. Because of this reason, all grades of Spans are most widely used in the proniosomal preparation. Fundamentally, all spans have the same head group but different alkyl chain. As per literatures, entrapment efficiency of formulation increases as the alkyl chain length increases as follows:

Span $60(\mathrm{C} 18)>\operatorname{Span} 40(\mathrm{C} 16)>$ Span $20(\mathrm{C} 12)>\operatorname{Span} 80(\mathrm{C} 18)$.

Spans 60 and 80 have the same head group, but it have difference in the alkyl chain (Span 80 have unsaturated alkyl chain). Because of the presence of a double bond, the paraffin chain of Span 80 causes a marked increase in the permeability and result in the low entrapment efficiency.

Addition of cholesterol in the formulation it suppresses the tendency of the surfactants to form aggregates and also provides stability to the bilayer membranes by increasing the gel liquid transition temperature of the vesicle and also attributes to the higher HLB and smaller critical packaging parameters. ${ }^{[21,43]}$

\section{METHOD OF PREPARATION}

\section{Coacervation phase separation}

It is widely used for the preparation of proniosomal gel. ${ }^{[44]} \mathrm{In}$ this method, cholesterol + surfactant + phosphatidyl choline + drug + a suitable alcohol are added in a wide-mouthed glass vial (minimum amount of suitable alcohol is added so that micelle formation does not take place). In general, the ratio for surfactant:alcohol:aqueous phase is 5:5:4 w/w/w. Mixing is done, and after that, it is covered with a lid to prevent the loss of solvent (warmed at $60-70^{\circ} \mathrm{C}$ on water bath). This process is repeated for $5 \mathrm{~min}$. until the surfactants are dissolved completely. Then, limited amount of aquous phase is added so, that gel formation can take place and not the dispersion, for example, diluted glycerol solution, isotonic buffer solution, and phosphate buffer or saline solution. The above solution on water bath is warmed till clear solution is formed, which on cooling converts into a proniosomal gel as shown in Figure 3. The gel which is obtained is preserved in the same glass tube in dark for characterization. After hydration of proniosomes, they are converted to uniformlysized niosomes. ${ }^{[45,46]}$

\section{Advantages}

1. The method is easy and not time consumable, hence it is essential specialized equipment

2. Specially adopted for gel preparation

3. Little quantities or small dose formulation can be prepared on lab scale

4. Specialized instrument is not required.

\section{Slurry method}

In this method, proniosomes can be prepared by the addition of the carrier powder and the entire surfactant solution to form slurry in a round-bottomed flask which is fitted to a rotary flask evaporator and vacuum is applied to form a dry and free-flowing powder. If the surfactant solution added is less in volume; then to get slurry, an additional amount of organic solvent can be added. The flask was removed from the evaporator and kept under vacuum overnight. Proniosome dry powder is collected, sealed in a container, and stored at $4^{\circ} \mathrm{C}$. The time required for proniosome production is independent 
of the ratio of surfactant solution to carrier material and appears to be stable. This method gives a uniform coating on carrier, it protects the active ingredients and surfactants from hydrolysis and oxidation. Along with that, the higher surface area results in a thinner surfactant coating, which makes the rehydration process more efficient. Solution is formed by the addition of surfactants and cholesterol in suitable solvent. ${ }^{[47-50]}$ The flask has to be attached to the a rotary flask evaporator to evaporate solvent at 50-60 rpm at

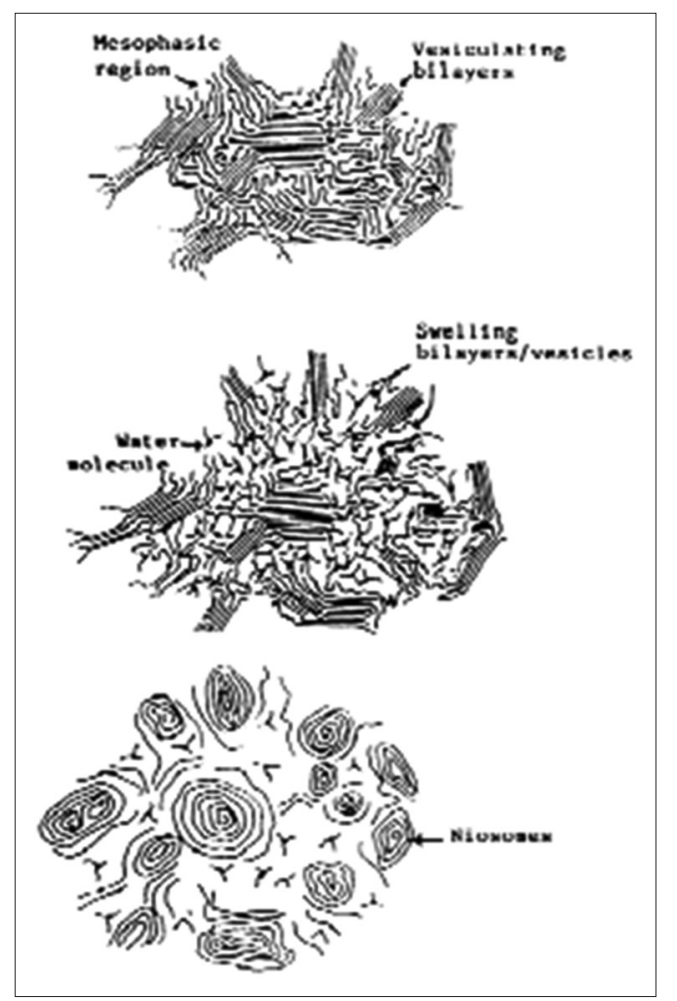

Figure 2: Formation of niosomes ${ }^{[32]}$ a temperature of $45 \pm 20^{\circ} \mathrm{C}$ and a reduced pressure of 600 $\mathrm{mmHg}$ until the mass in the flask had become a dry, freeflowing product.

\section{Advantages}

Due to the uniform coating on carrier it protects the active ingredients and surfactants from hydrolysis and oxidation.

a. The higher surface area results in a thinner surfactant coating, which makes the rehydration process more efficient.

b. Carrier material (e.g., maltodextrin is a polysaccharide) is easily soluble so water in that it is easy to coat the carrier particles by simply adding surfactant in organic solvents to dry carrier particles.

\section{Disadvantages}

a. The method is time-consuming and involves specialized equipment with vacuum and nitrogen gas.

b. The thin film approach allows only for a predetermined lot sizes, so material often wasted so small quantities or small dose batch can be tedious one.

\section{Slow spray coating method}

In this method, proniosomes are prepared by spraying surfactant in organic solvents onto the carrier and then evaporating the remaining solvent. For this, a $100 \mathrm{ml}$ roundbottomed flask containing desired amount of carrier can be attached to the rotary evaporator. A mixture of surfactants, cholesterol, and diacetyl phosphate should be prepared and introduced into the round-bottomed flask on the rotory evaporator by sequential spraying of aliquots onto carrier's (e.g., sorbitol powder) surface. During the spraying method, carrier surface does not become overly wet. For that reason,

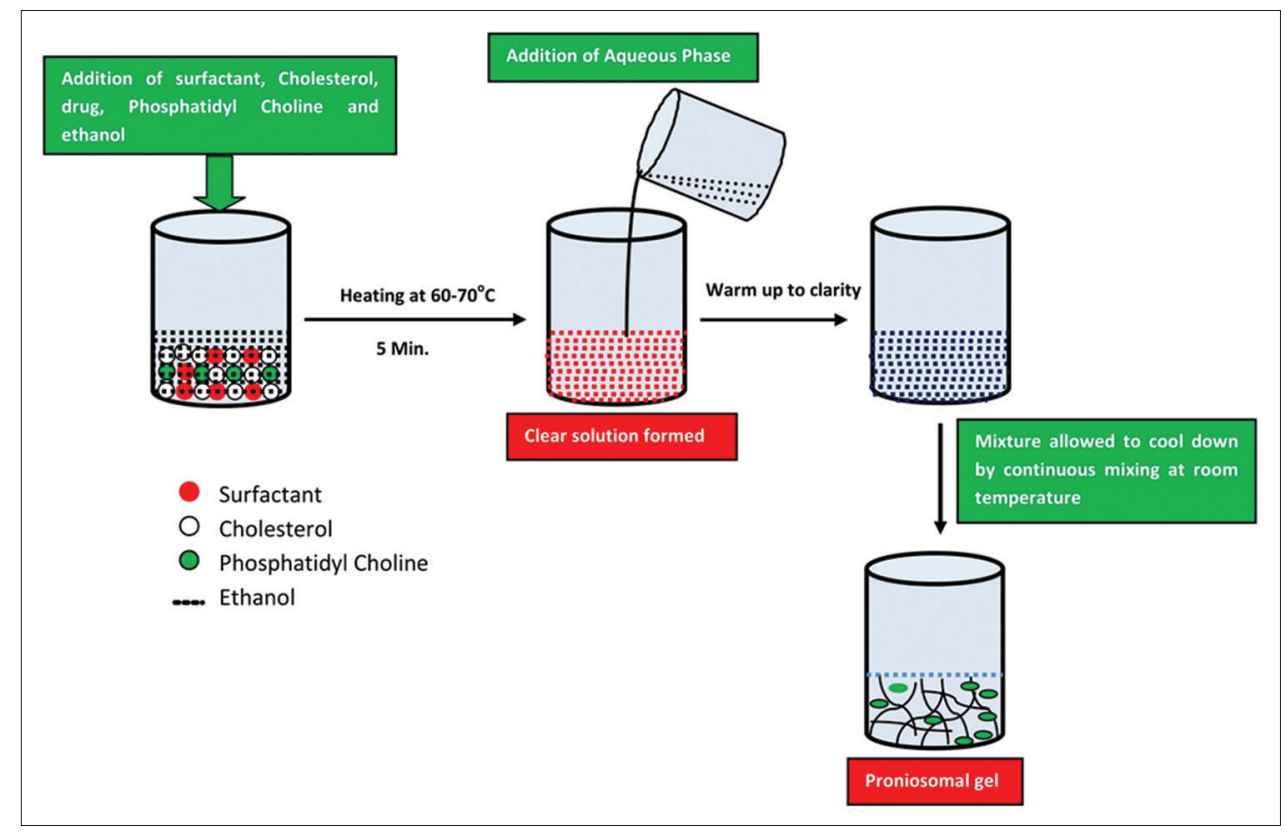

Figure 3: Coacervation phase separation method 
the rate of application is controlled. The evaporator has to be evacuated, rotating flask has to be rotated in a water bath under vacuum at $65-70^{\circ} \mathrm{C}$, and the flask has to be rotated under vacuum for $15-20$, min, or after the addition of final aliquots the evaporation should be continued until the powder becomes completely dry. This process is repeated until the surfactant solution has been applied. It is necessary to repeat the process until the desired surfactant loading has been achieved, because the carrier is soluble in the organic solvent. The surfactant coating on the carrier is very thin and hydration of this coating allows multilamellar vesicles to form as the carrier dissolves. The resulting niosomes have uniform size distribution similar to those produced by conventional methods by comparing the release rates. The material is further dried in desiccators under vacuum at room temperature overnight. Thus, a dry preparation is obtained; this dry preparation is referred to as "proniosome" and is used for the preparation and for the further study. Proniosome-derived niosome dispersion is obtained by hydrating proniosome preparation with $80^{\circ} \mathrm{C}$ distilled water and vortex mixing for $2 \mathrm{~min} \cdot{ }^{[51-54]}$

\section{Advantages $^{[50,55,56]}$}

Theadvantages are simplemethod and suitable forhydrophobic drug without concerns of instability or susceptibility of active pharmaceutical ingredient to hydrolysis.

\section{Disadvantages}

a. If the coating of surfactant solution was applied too quickly, the sorbitol particles would degrade and sample becomes viscous slurry.

b. This method was reported to be tedious since the sorbitol carrier for formulating proniosomes is soluble in the solvent used to deposit the surfactant.

c. Carrier is found to interfere with the encapsulation efficiency of the drug.

\section{COMPONENTS OF PRONIOSOMES}

Proniosomes comprise a variety of ingredients which are as follows.

\section{Non-ionic surfactants}

Surfactants are the surface active agents, usually organic compounds, that are amphiphilic in nature. Nonionic surfactants are the most common type of surface active agent used in preparing vesicles due to the superior benefits they impart with respect to stability, compatibility, and toxicity, compared to their anionic, amphoteric, or cationic counterparts. ${ }^{[57-59]}$ They are generally less toxic, less hemolytic, and less irritating to cellular surfaces and tend to maintain near physiological $\mathrm{pH}$ in solution. They have many functions including acting as solubilizers, wetting agents, emulsifiers, and permeability enhancers. They are also strong P-glycoprotein inhibitors, a property useful for enhancing drug absorption and for targeting specific tissues. ${ }^{[60]}$

Nonionic surfactants comprise both polar and nonpolar segments and possess high interfacial activity. A wide range of surfactant is available (Table 1). So, selection of surfactant should be doneon as, we have seen that for the formation of bilayer vesicles, instead, micelles are dependent on the HLB of the surfactant, the chemical structure of the components, and the CPP as we seen previously. Now, these factors in detail are to select proper surfactant:

I. HLB value: The HLB value of a surfactant plays a key role in controlling drug entrapment of the vesicle it forms. A surfactant with an HLB value in the range of 14-17 is not suitable to produce non-ionic surfactant vesicles whereas one with an HLB value of 8.6 gives vesicles with the highest entrapment efficiency is suitable. Entrapment efficiency decreases as the HLB value decreases from 8.6 to $1.7 .{ }^{[61,62]}$ Surfactant having HLB number in between 4 and 8 is a good candidate for vesicle formation. ${ }^{[63]}$ When the hydrophilic surfactants are taken into account their high aqueous solubility on hydration does not allow them to attain concentrated systems and it inhibit the free hydrated units to exist as aggregates and coalesced to form lamellar structure. High-HLB value results in reduction of surface-free energy which allows forming vesicles of larger size. ${ }^{[64]}$ The most common non-ionic surfactants used for vesicle formation are alkyl ethers, alkyl esters, alkyl amides, and esters of fatty acids. ${ }^{[6]}$ The encapsulation efficiency of Tween is relatively low as compared to span. ${ }^{[66]}$ Because of the larger size of vesicles and less lipophilic nature of tween, when span is used it also increases the lipophilicity of the drug. ${ }^{[67]}$

II. CPP: It can be defined as the relationship between the structure of the surfactant including size of hydrophilic head group and length of hydrophobic alkyl chain in the ability to form vesicles. On the basis of the CPP of a surfactant, the type of vesicle, which it will form, can be predicted. The chain length and size of the hydrophilic head group of the nonionic surfactant affect the entrapment efficiency of the drug. Non-ionic surfactants with stearyl (C18) chains show higher entrapment efficiency than those with lauryl (C12) chains. The Tween series of surfactants bearing a long alkyl chain and a large hydrophilic moiety in combination with cholesterol in a 1:1 ratio have the highest entrapment efficiency of water-soluble drugs. ${ }^{[68,69]}$

III. Phase transition temperature: Phase transition temperature plays a vital role in the degree of entrapment, as the transition temperature of surfactants increase, it leads to increase in the entrapment efficiency and decrease in the permeability. Spans with highest phase transition temperature provide the highest entrapment for the drug and vice versa. The drug leaching from the 
vesicles can be reduced due to a high-phase transition temperature and low permeability. ${ }^{[70]}$ The Span 60 with a high Tc exhibits the highest entrapment efficiency. ${ }^{[71]}$

IV. No significant difference is observed in the skin permeation profile of formulation containing Span 60 and Span 40 due to their higher phase transition temperature that is responsible for their lower permeability. ${ }^{[72,73]}$

\section{Cholesterol}

The Tween series of surfactants bearing a long alkyl chain and a large hydrophilic moiety in combination with cholesterol in a 1:1 ratio have the highest entrapment efficiency of watersoluble drugs. ${ }^{[74]}$ It is also seen that the addition of cholesterol enhances the stability of vesicles. It is mainly used as membrane stabilizer. Cholesterol is a naturally occurring

\section{Table 1: Surfactants and their properties ${ }^{[3,12]}$}

\begin{tabular}{|c|c|c|}
\hline Surfactant & Synonyms & Properties \\
\hline Sorbitan monolaurate & Span 20, Sorbitan mono dodecanoate & $\begin{array}{l}\text { Tc: } 16^{\circ} \mathrm{C} \\
\text { Density: } 1.032 \mathrm{~g} / \mathrm{mL} \text { at } 25^{\circ} \mathrm{C}(\mathrm{L}) \\
\text { Flash point: }>230^{\circ} \mathrm{F} \\
\text { HLB value: } 8.6\end{array}$ \\
\hline Sorbitan monopalmitate & Span 40 & $\begin{array}{l}\text { Tc: } 42^{\circ} \mathrm{C} \\
\text { Flash point: } 113^{\circ} \mathrm{C} \\
\text { Melting point: } 46-47^{\circ} \mathrm{C} \\
\text { HLB value: } 6.7\end{array}$ \\
\hline Sorbitan monostearate & Span 60 , sorbitan monooctadecanoate & $\begin{array}{l}\text { Tc: } 53^{\circ} \mathrm{C} \\
\text { Flash point: }>110^{\circ} \mathrm{C} \\
\text { Melting point: } 54-57^{\circ} \mathrm{C} \\
\text { HLB value: } 4.7\end{array}$ \\
\hline Sorbitan monooleate & $\begin{array}{l}\text { Span 80, } \\
\text { sorbitan (Z)-mono-9-octadecenoate }\end{array}$ & $\begin{array}{l}\text { TC: }-12^{\circ} \mathrm{C} \\
\text { Flash point: }>110^{\circ} \mathrm{C} \\
\text { Density: } 0.986 \\
\text { HLB value: } 4.3\end{array}$ \\
\hline $\begin{array}{l}\text { Polyoxyethylene }(20) \\
\text { sorbitan monolaurate }\end{array}$ & Tween 20 & $\begin{array}{l}\text { Density: } 1.106 \\
\text { Aqueous solubility: } 100 \mathrm{~g} / \mathrm{L} \\
\text { Boiling point: } 100^{\circ} \mathrm{C} \\
\text { HLB value: } 16.7\end{array}$ \\
\hline $\begin{array}{l}\text { Polyoxyethylene (20) } \\
\text { sorbitan monopalmitate }\end{array}$ & Tween 40 & $\begin{array}{l}\text { Density: } 1.05 \\
\text { Aqueous solubility: } 100 \mathrm{~g} / \mathrm{L} \\
\text { Boiling point: } 0.1^{\circ} \mathrm{C} \\
\text { HLB value: } 15.6\end{array}$ \\
\hline $\begin{array}{l}\text { Polyoxyethylene }(20) \\
\text { sorbitan monostearate }\end{array}$ & Tween 60 & $\begin{array}{l}\text { Density: } 1.081 \\
\text { Aqueous solubility: } 100 \mathrm{~g} / \mathrm{L} \\
\text { HLB value: } 14.9\end{array}$ \\
\hline $\begin{array}{l}\text { Polyoxyethylene (20) } \\
\text { sorbitan monooleate }\end{array}$ & Tween 80 & $\begin{array}{l}\text { Density: } 1.064 \\
\text { Aqueous solubility: } 5-10 \mathrm{~g} / 100 \mathrm{~mL} \text { at } 23^{\circ} \mathrm{C} \\
\text { Flash point: }>110^{\circ} \mathrm{C} \\
\text { HLB value: } 15.0\end{array}$ \\
\hline Sugar stearate & $\begin{array}{l}\text { S-1670 } \\
\text { S-970 } \\
\text { S-370 }\end{array}$ & $\begin{array}{l}\text { HLB-16 } \\
\text { HLB-9 } \\
\text { HLB-3 }\end{array}$ \\
\hline Sucrose palmitate & P-1670 & HLB-16 \\
\hline Sucrose myristate & M-1695 & HLB-16 \\
\hline Sucrose laureate & L-1695 & HLB-16 \\
\hline $\begin{array}{l}\text { Polyoxyethylene } 4 \\
\text { lauryl ether }\end{array}$ & Brij30 & $\begin{array}{l}\text { HLB- } 9.7 \\
\text { TC- } 10^{\circ} \mathrm{C}\end{array}$ \\
\hline $\begin{array}{l}\text { Polyoxyethylene } \\
\text { cetylether }\end{array}$ & Brij 58 & HLB-15.7 \\
\hline $\begin{array}{l}\text { Polyoxyethylene } \\
\text { stearylethers }\end{array}$ & $\begin{array}{l}\text { Brij } 72 \\
\text { Brij } 76\end{array}$ & $\begin{array}{l}\text { HLB-4.9 } \\
\text { HLB-12.4 }\end{array}$ \\
\hline
\end{tabular}

Tc: Phase transition temperature, HLB: Hydrophilic lipophilic balance 
steroid used as membrane additive. It prevents aggregation by the inclusion of molecules that stabilize the system against the formation of aggregate by repulsive steric or electrostatic effects. It leads transition from the gel state to liquid phase in niosome system.

El-Laithy et al. reported that as the cholesterol content increases, there is a significant increase in entrapment efficiency (\%), but after a certain limit, further cholesterol increase results in a significant decrease in entrapment efficiency. Because, cholesterol molecules accommodate itself as "vesicular cement" in the molecular cavities formed, when surfactant monomers are assembled into bilayers to form niosomal membranes, and this space filling action results in the increased rigidity, decreased permeability of cholesterol-containing membranes compared to cholesterol-free membranes, and the improved entrapment efficiency. On further increase of cholesterol beyond certain concentration, it competes with the drug for the space within the bilayers, hence excluding the drug and can disrupt the regular linear structure of vesicular membranes. ${ }^{[17,75,76]}$ Effect of cholesterol concentration was reported by several workers; one of them is mentioned here, entrapment into span 20 is not significantly altered by cholesterol. While in the case of span 80, a significant increase in entrapment is found. This can be explained on the basis of lowest phase transition temperature due to unsaturation present in oleate side chain. ${ }^{[77]}$

\section{Lecithin}

According to their source of origin, it is named soya lecithin which is from soya beans, and egg lecithin, which is from egg yolk. Phosphatidyl choline is such a major component of lecithin. In the vesicular system, it plays a number of important roles such as:

- It acts as permeation enhancers.

- Prevents the leakage of drug from vesicles.

- It helps in enhanced percent drug entrapment due to high Tc (phase transition temperature).

- It leads to form smaller size vesicles due an to increase in hydrophobicity which results in the reduction of vesicle size, further that vesicle composed of soya lecithin is of larger size then vesicle composed of egg lecithin.

- As it is a phospholipid, it is well tolerated from physiological point of view. Lecithin is GRAS-listed by the FDA and appears in many drugs monograph. Lecithin is also listed in FDA-inactive ingredients guide. ${ }^{[78]}$

- Penetration capability of soya lecithin is a better candidate to select as it contains unsaturated fatty acid, oleic and linoleic acids whereas the egg lecithin contains the saturated fatty acid.

- Lecithin provides stability, but to a lesser extent as compared to cholesterol.

\section{Carrier}

The carrier when used in the proniosomes preparation permits the flexibility in the ratio of surfactant and other components that is incorporated. It increases the surface area and gives efficient loading. The carriers should be safe and non-toxic, free flowing, poor solubility in the loaded mixture solution, and good water solubility for ease of hydration. ${ }^{[79,80]}$ The commonly used carriers are maltodextrin, sorbitol,

\begin{tabular}{|c|c|}
\hline Parameters & Techniques and instrument \\
\hline \multirow[t]{2}{*}{ Angle of repose } & Funnel method ${ }^{[86]}$ \\
\hline & Cylinder method ${ }^{[87]}$ \\
\hline $\begin{array}{l}\text { Aerodynamic } \\
\text { behavior }{ }^{[88]}\end{array}$ & Twin-stage impinge \\
\hline \multirow{4}{*}{$\begin{array}{l}\text { Particle/vesicle size } \\
\text { and size distribution }{ }^{[89]}\end{array}$} & Malvern mastersizer \\
\hline & Optical microscopy \\
\hline & $\begin{array}{l}\text { Laser diffraction particle size } \\
\text { analyzer Coulter submicron } \\
\text { size analyzer }\end{array}$ \\
\hline & $\begin{array}{l}\text { Photon correlation } \\
\text { spectroscopy }{ }^{[90]}\end{array}$ \\
\hline \multirow{2}{*}{$\begin{array}{l}\text { Determination } \\
\text { of entrapment } \\
\text { efficiency }{ }^{[89]}\end{array}$} & $\begin{array}{l}\text { Vesicle lysis using alcohol and } \\
\text { propylene glycol }\end{array}$ \\
\hline & Dialysis method \\
\hline \multirow[t]{4}{*}{$\begin{array}{l}\text { Shape and surface } \\
\text { morphology }\end{array}$} & $\begin{array}{l}\text { Scanning electron } \\
\text { microscopy (SEM) }\end{array}$ \\
\hline & Transmission electron \\
\hline & microscopy (TEM) \\
\hline & Optical microscopy \\
\hline Sieve fractionation ${ }^{[91]}$ & Fritsch analysette sieve shaker \\
\hline $\begin{array}{l}\text { Spontaneity } \\
\text { (rate of hydration) }^{[92]}\end{array}$ & Neubaur's chamber \\
\hline \multirow{4}{*}{$\begin{array}{l}\text { Separation of } \\
\text { unentrapped drugg }\end{array}$} & Exhaustive dialysis \\
\hline & Centrifugation (below $7000 \times g$ ) \\
\hline & Ultracentrifugation $(150,000 \times g)$ \\
\hline & Gel filtration \\
\hline \multirow{6}{*}{$\begin{array}{l}\text { In vitro drug release } \\
\text { studies }^{[89]}\end{array}$} & Franz diffusion cells \\
\hline & Keshary-chein diffusion cell \\
\hline & $\begin{array}{l}\text { Cellophane dialyzing } \\
\text { membrane }^{[93]}\end{array}$ \\
\hline & $\begin{array}{l}\text { Spectarpor molecular porous } \\
\text { membrane tubing }\end{array}$ \\
\hline & In vitro skin permeation studies \\
\hline & $\begin{array}{l}\text { USP dissolution } \\
\text { apparatus-[194,95] }\end{array}$ \\
\hline
\end{tabular}


mannitol, spray-dried lactose, glucose monohydrate, lactose monohydrate, and sucrose stearate.

\section{Solvent}

Selection of solvent is another important aspect as it causes a huge impact on vesicle size and drug permeation rate. ${ }^{[81]}$ According to literature survey vesicles formed from different types of alcohols are of different sizes and they depends on the solubility of alcohol in water. As the solubility of alcohol in water increases, the size of vesicles also increases and they follow the order below: ${ }^{[82]}$

Ethanol $>$ propanol $>$ butanol $>$ isopropanol.

Solvent can act as penetration enhancer. It also affects the spontaneity of the formation of niosomes. The formulation containing isopropanol and butanol was formed more spontaneously than niosomes containing propanol and ethanol due to faster phase separation of isopropanol and butanol and due to their lower solubility in water. As the isopropanolol showed smaller vesicular size due to branching in addition, reports suggest that the drug penetration is maximal for isopropanol due to the reason that the branched structure will act as co-surfactant and might loosen the bilayer packing into the increased release of drug. Ethanol may cause the reduction of lipid polar head interactions within the membrane, thereby increasing the skin permeation. ${ }^{[83,84]}$

\section{Aqueous phase}

Phosphate buffer (pH - 7.4), 0.1\% glycerol, and hot water are mainly used in the aqueous phase in preparation proniosomes. $\mathrm{pH}$ of the hydrating medium also play an important role in entrapment efficiency, it is due to the aqueous phase might affect the tactness of proniosomes. ${ }^{[43]}$ According to literature, it was found that $\mathrm{pH}$ of the hydrating medium shows variation in entrapment efficiency. As the $\mathrm{pH}$ decreased from $\mathrm{pH} 8$ to 5.5 there is an increase in the fraction of drug encapsulated increased. The increase in the percentage encapsulation efficiency of drug by decreasing the $\mathrm{pH}$ may be attributed to the presence of the ionizable carboxylic group in its chemical structure. Decrease in the $\mathrm{pH}$ leads to proportion increase in the unionized species of flurbiprofen, which have higher partitioning to the bilayer lipid phase compared to the ionized species. ${ }^{[85]}$

\section{Drug}

There are different groups of medication choices for proniosomes development but, they should have the following characteristics: ${ }^{[26]}$

- Low aqueous solubility drugs

Table 3: Different studies related to the application of proniosome

\begin{tabular}{|c|c|c|c|}
\hline Drug & Category & Result & References \\
\hline Tenoxicam & Anti-inflammatory properties & $\begin{array}{l}\text { The investigated proniosomal gel proved superior to } \\
\text { the oral market tablets in anti-inflamatory action }\end{array}$ & [20] \\
\hline Ketorolac & NSAIDs & $\begin{array}{l}\text { Proniosomes prepared with span } 60 \text { provided a } \\
\text { higher ketorolac flux across the skin than did those } \\
\text { prepared with Tween } 20\end{array}$ & [40] \\
\hline Guggul lipid & Herbal & Proved superior to the NSAIDS exiting in the market & [96] \\
\hline Levonorgestrel & Contraceptive agent & $\begin{array}{l}\text { The study demonstrated the utility of proniosomal } \\
\text { transdermal patch bearing levonorgestrel for } \\
\text { effective contraception }\end{array}$ & [32] \\
\hline Estradiol & Hormonal insufficiencies & $\begin{array}{l}\text { The encapsulation (\%) of proniosomes with Span } \\
\text { surfactants showed a very high value of } 100 \% \text {. }\end{array}$ & [30] \\
\hline Carvedilol & Antihypertensive & $\begin{array}{l}\text { Proniosomal gel for improved transdermal delivery } \\
\text { were investingated using various surfactants }\end{array}$ & [97] \\
\hline Tacrolimus & Immunosuppressive agent & $\begin{array}{l}\text { Proniosome-derived niosomes may } b \text { e a promising } \\
\text { vehicle for effective ocular drug delivery of tacrolimus }\end{array}$ & [98] \\
\hline Valsartan & Antihypertenive & $\begin{array}{l}\text { The encapsulation efficiency of span } 60 \text { was superior } \\
\text { to span } 40\end{array}$ & [99] \\
\hline Metformin & Anti-diabetic agent & $\begin{array}{l}\text { Metformin proniosomal gel is promising prolonged } \\
\text { drug delivery system and has reasonably good } \\
\text { stability characteristics }\end{array}$ & [100] \\
\hline Celecoxib & NSAIDs & $\begin{array}{l}\text { The pronisomal formulation improved the extent of } \\
\text { absorption than conventional capsules }\end{array}$ & [90] \\
\hline Neem seed oil & $\begin{array}{l}\text { Therapeutic and cosmetic } \\
\text { agent }\end{array}$ & $\begin{array}{l}\text { Prepare an acceptable pronisomal gel of neem seed } \\
\text { oil for therapeutic applications }\end{array}$ & [101] \\
\hline
\end{tabular}


Table 4: Patents related to proniosome and niosome

\begin{tabular}{|c|c|c|c|}
\hline Patent publication number & Inventors & Title & References \\
\hline US 4830857A & $\begin{array}{l}\text { R. Handjani, A. Ribier, } \\
\text { G. Vanlerberghe, } \\
\text { A. Zabotto, J. Griat }\end{array}$ & $\begin{array}{l}\text { Cosmetic and pharmaceutical compositions } \\
\text { containing niosomes and a water-soluble } \\
\text { polyamide, and a process for preparing these } \\
\text { compositions }\end{array}$ & [102] \\
\hline US 6051250 & $\begin{array}{l}\text { Ribier, A. Simonnet, } \\
\text { Jean-thierry }\end{array}$ & $\begin{array}{l}\text { Process for the stabilization of vesicles of } \\
\text { amphiphilic lipid (s) and composition for topical } \\
\text { application containing the said stabilized vesicle }\end{array}$ & [103] \\
\hline US 06576625B2 & A. Singh, R. Jain & $\begin{array}{l}\text { Targeted vesicular constructs for cytoprotection } \\
\text { and treatment of } \mathrm{H} \text {. pylori infections }\end{array}$ & [104] \\
\hline US 06951655B2 & Y. Cho, K. H. Lee & Pro-micelle pharmaceutical compositions & [105] \\
\hline WO/2010/12346 & Madhavan, Eva-Kathrin & Madanagopal. Vesicular Systems and Uses & [106] \\
\hline
\end{tabular}

- High-dose regularity drugs

- Low half-life

- Controlled medication distribution appropriate drugs

- Higher negative medication responses drugs.

\section{EVALUATION PARAMETERS}

Various techniques used for the optimization of the proniosomal gel are shown in Table 2.

\section{APPLICATIONS OF PRONIOSOMES}

The following are the few uses of proniosomes which are either proven or under research (Table 3).

\section{PATENTS RELATED TO PRONIOSOME AND NIOSOME}

The following are the few patents related to proniosome and niosome (Table 4).

\section{FUTURE TRENDS}

Studies on proniosome gel formulation indicate that it has become a useful dosage form for drug permeation into the skin, especially due to their simple, scaling-up production procedure and ability to modulate drug delivery across the skin. There is a strong need for exploring the proniosomal delivery systems for cosmetics, herbal actives, and nutraceuticals. Use of proniosome in the cosmetic formulation will lead to prolong action, better absorption along with many advantages.

\section{CONCLUSION}

Proniosomes are a novel and efficient approach to drug delivery. Their vesicular membrane is mainly composed of nonionic surfactants and cholesterol, and the enclosed interior usually contains a buffer solution at appropriate $\mathrm{pH}$. Proniosomes may be prepared by various methods, which affect their formations along with the properties of the drug, cholesterol content, and amount, structure, and type of surfactant. They improve the stability of the entrapped drug during delivery. They do not require special conditions for handling, protection, storage, or industrial manufacturing. In addition, they can be prepared with different structural characteristics (composition, fluidity, and size), and can be designed for particular routes of administration. Overall, proniosomes are a very effective tool for drug delivery and targeting of numerous therapeutically active moieties. They have the potential to provide better treatment than conventional drug delivery systems.

\section{REFERENCES}

1. Goyal P, Goyal K, Vijaya Kumar SG, SinghA, Katare OP, Mishra DN. Liposomal drug delivery systems - Clinical applications. Acta Pharm 2005;55:1-25.

2. Kakr R, Rao R, Goswami A, Nanda S, Saroha K. Proniosomes: An emerging vesicular system in drug delivery and cosmetics. Der Pharm Lett 2010;2:227-39.

3. Cevc G. Transfersomes, liposomes and other lipid suspensions on the skin: Permeation enhancement, vesicle penetration, and transdermal drug delivery. Crit Rev Ther Drug Carrier Syst 1996;13:257-388.

4. Kaneda Y. Virosomes: Evolution of the liposome as a targeted drug delivery system. Adv Drug Deliv Rev 2000;43:197-205.

5. Dubey S, Jain A, Mehta SC, Gupta P, Jain S, Sahu J. Niosomes: The ultimate drug carrier. Drug Invent Today 2010;2:72-7.

6. Vale CA, Corvo ML, Martins LC, Marques CR, Storm G, Cruz ME, et al. Construction of enzymosomes: Optimization of coupling parameters. NSTI Nanotech 2006;2:396-7.

7. Gaspar MM, Martins MB, Corvo ML, Cruz ME. Design and characterization of enzymosomes with surfaceexposed superoxide dismutase. Biochim Biophys Acta 
2003;1609:211-7.

8. Walve JR, Bakliwal SR, Rane BR, Pawar SP. Transfersomes: A surrogated carrier for transdermal drug delivery system. Int J Appl Biol Pharm Technol 2011;2:204-13.

9. Kulkarni PR, Yadav JD, Vaidya KA, Gandh PP. Transferosomes: An emerging tool for transdermal drug delivery. Int J Pharm Sci Res 2011;2:735-41.

10. Kish-Trier E, Hill CP. Structural biology of the proteasome. Annu Rev Biophys 2013;42:29-49.

11. Saraf S, Paliwal S, Saraf S. Sphingosomes a novel approach to vesicular drug delivery. Int J Cur Sci Res 2011;1:63-8.

12. González-Paredes A, Manconi M, Caddeo C, RamosCormenzana A, Monteoliva-Sánchez M, Fadda AM. Archaeosomes as carriers for topical delivery of betamethasone dipropionate: In vitro skin permeation study. J Liposome Res 2010;20:269-76.

13. Barbeau J, Cammas-Marion S, Auvray P, Benvegnu T. Preparation and characterization of stealth archaeosomes based on a synthetic PEGylated archaeal tetraether lipid. J Drug Deliv 2011;2011:396068.

14. Rattanapak T, Young K, Rades T, Hook S. Comparative study of liposomes, transfersomes, ethosomes and cubosomes for transcutaneous immunisation: Characterisation and in vitro skin penetration. J Pharm Pharmacol 2012;64:1560-9.

15. Vijayakumar MR, Sathalia AH, Arun K. Formulation and evaluation of diclofenac potassium ethosomes. Int J Pharm Pharm Sci 2010;2:82-6.

16. Kavitha D, Sowjanya J, Panaganti S. Pharmacosomes: An emerging vesicular system. Int J Pharm Sci Rev Res 2010;5:168-71.

17. El-Laithy HM, Shoukry O, Mahran LG. Novel sugar esters proniosomes for transdermal delivery of vinpocetine: Preclinical and clinical studies. Eur $\mathrm{J}$ Pharm Biopharm 2011;77:43-55.

18. Ijeoma FV, Vyas SP. Non-ionic surfactant based vesicles (niosomes) in drug delivery. Int $\mathrm{J}$ Pharm 1998;172:33-70.

19. Sharma BS, Bhogale V, Adepu AR, Patil ST, Sangha SK. Proniosomes: A novel provesicular drug delivery system. Int J Pharm Res Sch 2015;4:105-19.

20. Ammar HO, Ghorab M, El-Nahhas SA, Higazy IM. Proniosomes as a carrier system for transdermal delivery of tenoxicam. Int J Pharm 2011;405:142-52.

21. Walve JR, Rane BR, Gujrathi NA. Proniosomes: A surrogate carrier for improved transdermal drug delivery system. Int $\mathrm{J}$ Res Ayurveda Pharm 2011;2:743-50.

22. Schreier H, Bouwstra J. Liposomes and niosomes as topical drug carriers - Dermal and transdermal drugdelivery. J Control Rel 1994;30:1-15.

23. Baillie AJ, Florence AT, Hume LR, Muirhead GT, Rogerson A. The preparation and properties of niosomes - Non-ionic surfactant vesicles. J Pharm Pharmacol 1985;37:863-8.
24. Shukla ND, Tiwari M. Proniosomal drug delivery system - Clinical applications. Int J Res Pharm Biomed Sci 2011;2:880-7.

25. Akhilesh D, Hazel G, Kamath JV. Proniosomes - A propitious provesicular drug carrier. Int J Pharm Pharm Sci Res 2011;1:98-103.

26. Kumar K, Rai AK. Development and evaluation of proniosomes as a promising drug carrier to improve transdermal drug delivery. IRJP 2011;2:71-4.

27. Jha AK, Kumar R, Kumar S, Jha SS. Vesicular system - Carrier for drug delivery. Der Pharm Sin 2011;2:192-202.

28. Cserháti T. Alkyl ethoxylated and alkylphenol ethoxylated nonionic surfactants: Interaction with bioactive compounds and biological effects. Environ Health Perspect 1995;103:358-64.

29. Hofland HE, van der Geest R, Bodde HE, Junginger HE, Bouwstra JA. Estradiol permeation from nonionic surfactant vesicles through human stratum corneum in vitro. Pharm Res 1994;11:659-64.

30. Fang JY, Yu SY, Wu PC, Huang YB, Tsai YH. In vitro skin permeation of estradiol from various proniosome formulations. Int J Pharm 2001;215:91-9.

31. Gupta A, Prajapati SK, Balamurugan M, Singh M, Bhatia D. Design and development of a proniosomal transdermal drug delivery systems for captopril. Trop J Pharm Res 2007;6:687-93.

32. Vora B, Khopade AJ, Jain NK. Proniosome based transdermal delivery of levonorgestrel for effective contraception. J Control Release 1998;54:149-65.

33. Blazek-Welsh AI, Rhodes DG. Maltodextrin - Based proniosomes. AAPS PharmSciTech 2001;3:1-9.

34. Blazek-Welsh AI, Rhodes DG. SEM imaging predicts quality of niosomes from maltodextrin-based proniosomes. Pharm Res 2001;18:656-61.

35. Jufri M, Effionora A, Joshita D. Preparation of maltodextrin DE 5-10 based ibuprofen proniosomes. Majalah Ilmu Kefarmasian I 2004;1:10-2036.

36. Solanki AB, Parikh JR, Parikh RH. Formulation and optimization of piroxicam proniosomes by 3-factor, 3-level Box-Behnken design. AAPS PharmSciTech 2007;8:E86.

37. Giddi HS, Arunagirinathan MA, Bellare JR. Selfassembled surfactant nano-structures important in drug delivery: A review. Indian J Exp Biol 2007;45:133-59.

38. Comelles F, Sanchez-leal J, Gonzalez JJ. Influence of ionic surfactants on the formation of liquid crystals in oleic acid/glycol/water systems. J Surfactants Detergents 2007;10:137-44.

39. Murdan S, Gregoriadis G, Florence AT. Interaction of a nonionic surfactant-based organogel with aqueous media. Int J Pharm 1999;180:211-4.

40. Alsarra IA, Bosela AA, Ahmed SM, Mahrous GM. Proniosomes as a drug carrier for transdermal delivery of ketorolac. Eur J Pharm Biopharm 2005;59:485-90.

41. Perrett S, Golding M, Williams WP. A simple method for the preparation of liposomes for pharmaceutical 
applications: Characterization of the liposomes. J Pharm Pharmacol 1991;43:154-61.

42. El Maghraby GM, Ahmed AA, Osman MA. Penetration enhancers in proniosomes as new strategy for enhanced transdermal drug delivery. Saudi Pharm J 2015;23:67-74.

43. Murdan S, van den Bergh B, Gregoriadis G, Florence AT. Water-in-sorbitan monostearate organogels (water-inoil gels). J Pharm Sci 1999;88:615-9.

44. Varshosaz J, Pardakhty A, Baharanchi SM. Sorbitan monopalmitate-based proniosomes for transdermal delivery of chlorpheniramine maleate. Drug Deliv 2005; 12:75-82.

45. Iwai H, Fukasawa J, Suzuki T. A liquid crystal application in skin care cosmetics. Int J Cosmet Sci 1998;20:87-102.

46. Ram A, Thakur A, Mittal VK. Proniosomal provesicular system for transdermal delivery of hydralazine for hypertension. Asian J Pharm Clin Res 2012;5:1-7.

47. Barry BW. Novel mechanisms and devices to enable successful transdermal drug delivery. Eur J Pharm Sci 2001;14:101-14.

48. Mahdi J, Effionora A, Joshita D. Preparation of maltodextrin DE 5-10 based ibuprofen proniosomes. Majalah Ilmu Kefarmasian I 2004;1:10-20.

49. Aggarwal D, Garg A, Kaur IP. Development of a topical niosomal preparation of acetazolamide: Preparation and evaluation. J Pharm Pharmacol 2004;56:1509-17.

50. Shahiwala A, Misra A. Studies in topical application of niosomally entrapped nimesulide. J Pharm Pharm Sci 2002;5:220-5.

51. Azeem A, Jain N, Iqbal Z, Ahmad FJ, Aqil M, Talegaonkar S. Feasibility of proniosomes-based transdermal delivery of frusemide: Formulation optimization and pharmacotechnical evaluation. Pharm Dev Technol 2008;13:155-63.

52. Thakur R, Anwer MK, Shams MS, Ali A, Khar RK, Shakeel F, et al. Proniosomal transdermal therapeutic system of losartan potassium: Development and pharmacokinetic evaluation. J Drug Target 2009; 17:442-9.

53. Tiddy GJ. Surfactant - Water liquid crystal phases. Phys Rep 1980;57:1-46.

54. Hu C, Rhodes DG. Proniosomes: A novel drug carrier preparation. Int J Pharm 1999;185:23-35.

55. Rishu K, Rekha R, Anju G, Sanju N, Kamal S. Proniosomes: An emerging vesicular system in drug delivery and cosmetics. Sch Res Libr 2010;2:4, 227-39.

56. Youan BC, Hussain A, Nguyen NT. Evaluation of sucrose estersas alternative surfactants in microencapsulation of proteins by the solvent evaporation method. AAPS PharmSciTech 2003;5:125-32.

57. Jiao J. Polyoxyethylated nonionic surfactants and their applications in topical ocular drug delivery. Adv Drug Deliv Rev 2008;60:1663-73.

58. Zografi G. Interfacial phenomena. In: Gennaro AR, editor. Remington: The Science and Practice of Pharmacy. 17 $7^{\text {th }}$ ed. Pennsylvania: Mark Publishing;
1995. p. $241-51$.

59. Hall DG. Thermodynamics of micelle formation. In: Schick MJ, editor. Nonionic Surfactants: Physical Chemistry, Surfactant Science Series. Vol. 23. New York: Marcel Dekker; 1987. p. 233-96.

60. Zhang S, Morris ME. Efflux transporters in drug excretion In: Wang B, Siahaan T, Soltero R, editors. Drug Delivery: Principles and Applications. New Jersey: John Wiley \& Sons; 2005. p. 381-98.

61. Biswal S, Murthy PN, Sahu J, Sahoo P, Amir F. Vesicles of nonionic surfactants (niosomes) and drug delivery potential. Int J Pharm Sci Nanotechnol 2008;1:1-8.

62. Lawrence MJ, Chauhan S, Lawrence SM, Barlow DJ. The formation characterization and stability of nonionic surfactant vesicles. STP Pharm Sci 1996;1:49-60.

63. Kibbe AH. Handbook of Pharmaceutical Excipients. $3^{\text {rd }}$ ed. Washington, DC: American Pharmaceutical Association; 2000. p. 511-14.

64. Rawat AS, Kumar MS, Khurana B, Mahadevan N. Proniosome gel: A novel topical delivery system. Int J Rec Adv Pharm Res 2011;3:1-10.

65. Uchegbu IF, Vyas SP. Non-ionic surfactant based vesicles (niosomes) in drug delivery. Int $\mathrm{J}$ Pharm 1998;172:33-70.

66. Zhang JQ. Studies on lung targeted niosomes of carboplatin. Eur J Pharm Sci 2001;36:36-45.

67. Reddy DN, Udupa N. Formulation and evaluation of oral and transdermal preparations of flurbiprofen and piroxicam incorporated with different carriers. Drug Dev Ind Pharm 1993;19:843-52.

68. Uchegbu IF, Florence AT. Non-ionic surfactant vesicles (niosomes): Physical and pharmaceutical chemistry. Adv Colloid Interface Sci 1995;58:1-55.

69. Arunothayanun P, Bernard MS, Craig DQ, Uchegbu IF, Florence AT. The effect of processing variables on the physical characteristics of non-ionic surfactant vesicles (niosomes) formed from a hexadecyl diglycerol ether. Int J Pharm 2000;201:7-14.

70. Dahiya NK. Preparation andcharacterization technique in niosomal vesicularsystems - A review. J Pharm Biomed Sci 2011;5:1-8.

71. Gannu PK, Pogaku R. Nonionic surfactant vesicular systems for effective drug delivery - An overview. Acta Pharm Sin B 2011;1:208-19.

72. Hao Y, Zhao F, Li N, Yang Y, Li K. Studies on a high encapsulation of colchicine by a niosome system. Int $\mathrm{J}$ Pharm 2002;244:73-80.

73. Alli Malarkodi S, Srilakshmi C, Ganesan G. Proniosome gel: An effective novel therapeutic topical delivery system. Int J PharmTechRes 2013;5:1754-64.

74. Balakrishnan P, Shanmugam S, Lee WS, Lee WM, $\mathrm{Kim} \mathrm{JO}$, Oh $\mathrm{DH}$, et al. Formulation and in vitro assessment of minoxidil niosomes for enhanced skin delivery. Int J Pharm 2009;377:1-8.

75. Venkatesh DN, Priyanka VS, Tulasi K, Kalyani K, Ali SA, Jilakara H. Proniosomes: A superior drug delivery system. Int J Pharm Sci Drug Res 2014;6:178-82. 
76. Nasseri B. Effect of cholesterol and temperature on the elastic properties of niosomal membranes. Int J Pharm 2005;300:95-101.

77. Cable C. An Examination of the Effects of Surface Modifications on the Physiochemical and Biological Properties of Non-Ionic Surfactants Vesicles. PH.D. Thesis. Glasgow, UK: University of Strathclyde; 1993.

78. Leigh M. Modified Release Drug Delivery Technology. New York: Marshel Decker Inc.; 2002.

79. Akhilesh D, Faishal G, Kamath JV. Comparative study of carriers used in proniosomes. Int J Pharm Chem Sci 2012;1:164-73.

80. Pandey N. Proniosomes and ethosomes: New prospect in transdermal and dermal drug delivery system. IJPSR 2011;2:1988-96.

81. Ishii F, Takemura A, Ishigami Y. Procedure for preparation of lipid vesicles (Liposomes) using coacervation (phase separation) technique. Langmuir 1995;11:483-6.

82. Parikh DK, Ghosh TK. Feasibility of transdermal delivery of fluoxetine. AAPS PharmSciTech 2005;6:E144-9.

83. Annakula D, Errabelli MR, Jukanti R, Bandari S, Veerareddy PR. Provesicular drug delivery systems: An overview and appraisal. Arch Appl Sci Res 2010;2:135-46.

84. Megrab NA, Williams AC, Barry BW. Oestradiol permeation across human skin, silastic and snake skin membranes: The effects of ethanol/water cosolvent systems. Int J Pharm 1995; 116:101-12.

85. Mokhtar M, Sammour OA, Hammad MA, Megrab NA. Effect of some formulation parameters on flurbiprofen encapsulation and release rates of niosomes prepared from proniosomes. Int J Pharm 2008;361:104-11.

86. Raymond CR, Paul JS, Sian CO. Handbook of Pharmaceutical Excipients. $5^{\text {th }}$ ed. Great Britain: Pharmaceutical Press; 2006. p. 713-7, 580-4.

87. Radha GV, Rani TS, Sarvani B. A review on proniosomal drug delivery system for targeted drug action. J Basic Clin Pharm 2013;4:42-8.

88. Abd-Elbary A, El-laithy HM, Tadros MI. Sucrose stearate-based proniosome-derived niosomes for the nebulisable delivery of cromolyn sodium. Int J Pharm 2008;357:189-98.

89. Sankar V, Ruckmani K, Durga S, Jailani S. Proniosomes as drug carriers. Pak J Pharm Sci 2010;23:103-7.

90. Nasr M. In vitro and in vivo evaluation of proniosomes containing celecoxib for oral administration. AAPS PharmSciTech 2010;11:85-9.

91. Waghmode M, Ashar S. Proniosomal drug delivery systems: An overview. Int $\mathrm{J}$ Pharm Chem Sci 2012;1:1044-56.

92. Parthibarajan R, Rubinareichal C, Loganathan S. Formulation and evaluation of methotrexate proniosomal powder. Int J Pharm Pharm Sci 2012;4:175-8.
93. Yadav K, Yadav D, Saroha K, Nanda S, Mathur P. Proniosomal gel: A provesicular approach for transdermal drug delivery. Sch Res Libr 2010;2:189-98.

94. Prakash SG, Joshi VG. An engineered specificity of irinotecan loaded proniosomes: Design and characterization. Int J Drug Deliv 2011;3:472-80.

95. Aburahma MH, Abdelbary GA. Novel diphenyl dimethyl bicarboxylate provesicular powder with enhanced hepatoprotective activity: Preparation, optimization, in vitro/in vivo evaluation. Int J Pharm 2012;422:139-50.

96. Goyal C, Ahuja M, Sharma KS. Preparation and evaluation of anti inflammatory activity of guggul-lipid loaded proniosomal gel. Acta Poloniae Pharm Drug Res 2011;68:147-50.

97. Aboelwafa AA, El-Setouhy DA, Elmeshad AN . Comparative study on the effects of some polyoxyethylene alkyl ether and sorbitan fatty acid ester surfactants on the performance of transdermal carvedilol proniosomal gel using experimental design. AAPS PharmSciTech 2010;11:1591-602.

98. Li Q, Li Z, Zeng W, Ge S, Lu H, Wu AC, et al. Proniosome-derived niosomes for tacrolimus topical ocular delivery: In vitro cornea permeation, ocular irritation, and in vivo anti-allograft rejection. Eur $\mathrm{J}$ Pharm Sci 2014. (In press).

99. Kakkar R, Rao R, Dahiya NK, Nanda S. Formulation and characterisation of valsartan proniosomes. Maejo Int J Sci Technol 2010;5:146-58.

100. Loona S, Gupta N, Khan MU. Preparation and characterization of metformin proniosomal gel for treatment of diabetes mellitus. Int J Pharm Sci Rev Res 2012;21:108-14.

101. Chandel A, Saroha K, Nanda S. Preparation and evaluation of proniosomal gel of neem seed oil. Int $\mathrm{J}$ Pharm Sci Nanotechnol 2012;5(3):1780-4.

102. Handjani R, Ribier A, Vanlerberghe G, Zabotto A, Griat J. Cosmetic and pharmaceutical compositions containing niosomes and a water-soluble polyamide, and a process for preparing these compositions, U.S. Patent US 4830857A; 1989.

103. Ribier A, Simonnet JT. Process for the stabilization of vesicles of amphiphilic lipid(s) and composition for topical application containing the said stabilized vesicles, U.S. Patent US 6051250; 2000.

104. Singh A, Jain R. Targeted vesicular constructs for cytoprotection and treatment of $H$. pylori infections, U.S. Patent US 06576625B2; 2003.

105. Cho Y, Lee KH. Pro-micelle pharmaceutical compositions, U.S Patent US 06951655B2; 2005.

106. Madhavan N, Eva-Kathrin S, Madanagopal K. Vesicular Systems and Uses There of WO/2010/12346; 2010.

Source of Support: Nil. Conflict of Interest: None declared. 